\title{
Groundwater Recharge Estimation Using Comparison of Methods in Sirumugai Area of Coimbatore, Tamil Nadu, India
}

\author{
P. Natarajan ${ }^{1}$, S. V. Kottiswaran ${ }^{2}$, A. Balasubramanian ${ }^{3}$ and B. Palanikumaran ${ }^{4 *}$ \\ ${ }^{1}$ Forest College and Research Institute, Mettupalayam - 641301, Tamil Nadu, India \\ ${ }^{2}$ Agricultural Engineering College and Research Institute, Tamil Nadu Agricultural \\ University, Coimbatore-641 003, Tamil Nadu, India \\ ${ }^{3}$ Department of Silviculture, Forest College and Research Institute, Mettupalayam - 641301, \\ Tamil Nadu, India \\ ${ }^{4}$ Forest College and Research Institute, Hyderabad, Mulugu - 502279, Telangana, India \\ *Corresponding author
}

\section{A B S T R A C T}

\begin{tabular}{|l|}
\hline K e y w o r d s \\
$\begin{array}{l}\text { Groundwater, Recharge } \\
\text { estimation, comparison of } \\
\text { methods, empirical } \\
\text { formula }\end{array}$ \\
\hline Article Info \\
\hline $\begin{array}{l}\text { Accepted: } \\
\text { 15 May 2018 } \\
\text { Available Online: } \\
\text { 10 June 2018 }\end{array}$ \\
\hline
\end{tabular}

Groundwater is one of the most valuable natural resources, which supports human health, economic development and ecological diversity. The amount of water that will ultimately arrive at the water table is defined as natural ground water recharge. The amount of this recharge depends upon the rate and duration of rainfall, the subsequent conditions at the upper boundary, the antecedent soil moisture conditions, the water table depth and the soil type. The assessment of groundwater recharge from precipitation is a major part of hydrology and hydrogeology. The present study of groundwater recharge has been estimated at various locations in the Sirumugai study area which is located in the Coimbatore district, Tamil Nadu. The annual groundwater recharge, recharge coefficient have been estimated by using empirical methods and water table fluctuation method. The related rainfall data were collected from two rain gauge stations for the period of 1995 to 2014. The results showed that average groundwater recharge of six empirical methods and water table fluctuation method were varies with 5.51 to $101.20 \mathrm{~mm}$ per year and 67.5 to $340 \mathrm{~mm}$ per year respectively for the study area. Comparison of multiple methods is found to be valuable for determining the range of plausible recharge rates and for highlighting the uncertainty of the estimates.

\section{Introduction}

Groundwater is one of the most valuable natural resources, which supports human health, economic development and ecological diversity. Because of its several inherent qualities (e.g., consistent temperature, widespread and continuous availability, excellent natural quality, limited vulnerability, low development cost, drought reliability, etc.), it has become an immensely important and dependable source of water supplies in all climatic regions including both urban and rural areas of developed and developing countries (Todd and Mays, 2005). Particularly, groundwater is emerging as a formidable poverty alleviation tool, which can be delivered direct to poor community far more 
cheaply, quickly and easily than canal water (IWMI, 2001). Of the $37 \mathrm{Mkm}^{3}$ of freshwater estimated to be present on the earth, about $22 \%$ exists as groundwater, which constitutes about $97 \%$ of all liquid freshwater potentially available for human use (Foster, 1998).

Unfortunately, the excessive use and continued mismanagement of water resources to supply ever increasing water demands to profligate users have led to water shortages, increasing pollution of freshwater resources and degraded ecosystems worldwide (e.g., Clarke, 1991; Falkenmark and Lundqvist, 1997; de Villiers, 2000; Tsakiris, 2004).

It is now a well-recognized fact that water is a finite and vulnerable resource, and it must be used efficiently and in an ecologically sound manner for present and future generations. It is rightly said that groundwater will be an enduring gauge of this generation's intelligence in water and land management.

The recharge rate varies both spatially and temporally. Factors influencing groundwater recharge include characteristics of the recharge beds, such as topography, land use and vegetation cover, existing soil moisture and the ability of the recharge beds and aquifer materials to capture and transmit water (Bureau of Rural Science, 2007). Interest in quantifying recharge rate has increased because of concerns that land use changes may reduce recharge and that ground water resources in some areas may not be sustainable during drought periods (Risser $e t$ al., 2005).

For a given rainfall regime and soil moisture capacity, recharge is determined by the evapotranspirative demand of the plants. There are differences in the water demands of different crops, but the significant difference is between trees and woody shrubs on one hand and crops and pasture on the other.

\section{Materials and Methods}

\section{Study Area}

The Sirumugai Forest Range is situated in the Coimbatore Forest Division at $11^{\circ} 18^{\prime} \mathrm{N}$ latitude and $77^{\circ} 56^{\prime} \mathrm{E}$ longitude to $11^{\circ} 27^{\prime} \mathrm{N}$ latitude and $77^{\circ} 7^{\prime}$ E longitude and the altitude of the range is $300 \mathrm{~m}$ above mean sea level. The climate is semi-arid tropical type with hot summers and cold winters. The dry season starts from early February to mid-June and wet season from mid-August to early November.

The average annual rainfall is $913.9 \mathrm{~mm}$. North East monsoon contributes 80 per cent of the rainfall and balance 20 per cent of the rainfall is from South West monsoon and summer showers. The temperature of the study area is between $37^{\circ} \mathrm{C}$ maximum and minimum of $25^{\circ} \mathrm{C}$.

The study area exhibits different types of soil which are generally covered by red soils, of which red calcareous soil is predominant. Forest soils are confined to the reserve forest area and have a surface layer of organic matter. Forest soil is shallow in depth with red loamy, sandy and black clayey soil.

In plains the soils are shallow, thin and loamy and in higher elevations the soil is rich in humus. In the forest area trees, shrubs, herbs and grasses are covered and agricultural land major crops grown are banana, coconut and vegetables. Bhavani river is flowing west to east directions.

\section{Methods of recharge estimation}

Groundwater recharge was estimated in the Sirumugai forest range and agricultural land by using two methods viz., (1) Empirical methods and (2) Water table fluctuation method 


\section{Estimation of Groundwater recharge by using empirical formulae}

Natural groundwater recharge from rainfall was estimated by using the following empirical formulae (G.E.C. 2002)

\section{Chaturvedi Formula (1936)}

Based on water level fluctuation and rainfall amount in Ganga - Yamua doab, Chaturvedi, 1936 derived an empirical relationship to arrive at the recharge as a function of annual precipitation (Kumar, 1996).

$\mathrm{Rg}=2(\mathrm{P}-15) 0.4$--- (1)

Where, $\mathrm{Rg}$ is net recharge, in inches, $\mathrm{P}$ is annual rainfall, in inches.

This formula is useful for preliminary estimates of recharge due to rainfall. This formula later modified by U.P. Irrigation Research Institute.

\section{Amritsar Formula (1973)}

Using regression analysis for certain doabs in Punjab, the Irrigation and Power Research Institute, Amritsar, developed the following formula in 1973.

$\mathrm{Rr}=2.5(\mathrm{P}-16) 0.5--(2)$

Where, $\mathrm{Rr}$ and $\mathrm{P}$ are measured in inches.

\section{U.P.I.R.I. Formula (1954)}

The formula given by Uttar Pradesh Irrigation Research Institute, Roorkee, 1954 is as follows (Kumar, 1996),

$\operatorname{Rg}=1.35(\mathrm{P}-14) 0.5$--- (3)

Where $\mathrm{Rg}$ is net recharge, in inches, $\mathrm{P}$ is annual rainfall, in inches.

\section{Krishna Rao Formula (1970)}

Krishna Rao gave the following empirical relationship in 1970

To determine the groundwater recharge in limited climatological homogeneous areas of Karnataka state (Kumar, 1996).

$\mathrm{Rr}=\mathrm{K}(\mathrm{P}-\mathrm{X})$--- $(4)$

Where, $\mathrm{Rr}$ is groundwater recharge, $\mathrm{mm}, \mathrm{P}$ is precipitation, $\mathrm{mm}$ and $\mathrm{K}$ is recharge coefficient. Following relation holds good for different part of Karnataka,

$\mathrm{Rr}=0.20(\mathrm{P}-400)$ - Where annual rainfall between $400-600 \mathrm{~mm}$

$\mathrm{Rr}=0.25(\mathrm{P}-400)$ - Where annual rainfall between $600-1000 \mathrm{~mm}$

$\mathrm{Rr}=0.35(\mathrm{P}-600)-$ Where annual rainfall greater than $2000 \mathrm{~mm}$

\section{Bhattacharjee Formula (1954)}

Bhattacharjee, 1954 derived an empirical relationship for estimation of rainfall recharge (Annual report of AICRP on groundwater utilization, 2007-08),

$\mathrm{R}=3.47(\mathrm{P}-38) 0.4$--- (5)

Where, $\mathrm{R}$ is groundwater recharge, $\mathrm{cm}$ and $\mathrm{P}$ is precipitation, $\mathrm{cm}$

\section{Kumar and Seethapathi Formula (2002)}

Kumar and Seethapathi, 2002 proposed the following relationship for estimation of recharge from rainfall in upper Ganga canal command area (Kumar and Seethapathi formula 2002),

$\operatorname{Rg}=0.63(\mathrm{P}-15.28) 0.76--(6)$ 
Where $\mathrm{Rg}$ is groundwater recharge from rainfall in monsoon season (inches) and $\mathrm{P}$ is mean rainfall in monsoon season (inches).

\section{Estimation of Groundwater recharge by using water table fluctuation method}

Groundwater recharge was estimated by using water table fluctuation method. Water level fluctuation method is the most widely used method for recharge estimation. Healy and Cook, 2002 gave detailed procedure for estimating the groundwater recharge using the change in groundwater levels. The Groundwater Estimation Committee, 2002 recommended groundwater fluctuation method in estimating the groundwater recharge. The method is more scientific and takes into account the response of groundwater level fluctuation and specific yield, which are more, realistic and directly measurable, unlike other approaches where assumptions are to be made for most of the components. Two years (2013 and 2014) water table fluctuation data of the study area were used for groundwater recharge estimation of the Sirumugai area using the following formula;

$\mathrm{Rg}=\mathrm{Aw} * \ddot{\mathrm{A}} \mathrm{L} * \mathrm{Sy}---(8)$

Where, $\mathrm{Rg}$ is groundwater recharge, Aw is area of watershed $\left(\mathrm{m}^{2}\right)$, Sy is specific yield and $\ddot{\mathrm{A}} \mathrm{L}$ is water table difference (m). A constant specific yield (Sy) was taken as 0.25 , based on literature data.

\section{Results and Discussion}

\section{Groundwater recharge by using empirical formulae}

The long term daily data of 20 years from 1995 to 2014 of Sirumugai area is used to estimate the groundwater recharge by using the six empirical methods. The average monthly average values of rainfall are shown in Fig. 2 which indicates that more than $90 \%$ rainfall occurs during the monsoon seasons (April to December).

The estimation of recharge in the study area by U.P.I.R.I formula gives the smallest values of the six empirical approaches, and these values agree with Chaturvedi estimation for a semiarid area. The long-term mean of rainfall from 1995-2014 is used in the calculation for Sirumugai area. It must be borne in mind that there is high variability of rainfall in this area and a decreasing trend is observed from the high rainfall of the past.

This is considered while interpreting the recharge estimates. High recharge coincides with period of high rainfall and low recharge with low rainfall. Rain gauge station wise groundwater recharge estimated by the six empirical methods is given in Table 1, indicates the total groundwater recharge of the study area during the period from 1995 to 2014.

The estimated recharges with these empirical formulae were 5.96, 5.51, 15.07, 9.5, 43.53 and 101.20 millimeter respectively. The recharge with respect to rainfall varies from $5.51 \mathrm{~mm}$ to $101.20 \mathrm{~mm}$ with an average of $30.12 \mathrm{~mm}$.

\section{Estimation of recharge by water table fluctuation method}

For the computation of recharge using the WTF method, groundwater levels were recorded monthly from 2013 to 2014 in 12 open wells, as shown in Fig.3. A value of 2.5 per cent was assumed for the specific yield of the aquifer in the study area (a hard rock area) based on the guidelines of GEC of GOI, 2002. Based on the rise of the water table for each rainfall event, the annual rise in groundwater level was obtained as shown in Table 2. 
Int.J.Curr.Microbiol.App.Sci (2018) 7(6): 1433-1440

Table.1 Annual recharge calculation by using empirical methods

\begin{tabular}{|c|c|c|c|c|c|c|c|}
\hline $\begin{array}{l}\text { SI. } \\
\text { No. }\end{array}$ & Year & Chaturvedi & U.P.I.R.I & Bhattacharjee & Amritsar & $\begin{array}{l}\text { Seethapathi \& } \\
\text { Kumar }\end{array}$ & $\begin{array}{c}\text { Krishna } \\
\text { Rao }\end{array}$ \\
\hline 1. & 1995 & 3.80 & 3.30 & 9.63 & 4.98 & 32.31 & 21.67 \\
\hline 2. & 1996 & 5.87 & 5.36 & 14.84 & 9.28 & 32.58 & 89.61 \\
\hline 3. & 1997 & 7.83 & 7.56 & 19.76 & 13.54 & 86.27 & 194.09 \\
\hline 4. & 1998 & 5.96 & 5.46 & 15.06 & 9.47 & 47.8 & 93.18 \\
\hline 5. & 1999 & 6.44 & 5.98 & 16.27 & 10.50 & 52.59 & 114.08 \\
\hline 6. & 2000 & 5.82 & 5.30 & 14.69 & 9.16 & 38.99 & 87.31 \\
\hline 7. & 2001 & 5.98 & 5.48 & 15.12 & 9.52 & 51.03 & 94.11 \\
\hline 8. & 2002 & 2.25 & 2.07 & 5.80 & 1.49 & 28.07 & 3.24 \\
\hline 9. & 2003 & 5.32 & 4.78 & 13.45 & 8.13 & 26.61 & 69.06 \\
\hline 10. & 2004 & 6.37 & 5.90 & 16.10 & 10.35 & 37.92 & 110.96 \\
\hline 11. & 2005 & 7.08 & 6.69 & 17.88 & 11.89 & 54.73 & 145.7 \\
\hline 12. & 2006 & 6.46 & 6.00 & 16.32 & 10.54 & 53.45 & 115.00 \\
\hline 13. & 2007 & 5.57 & 5.04 & 14.07 & 8.64 & 27.37 & 77.77 \\
\hline 14. & 2008 & 6.90 & 6.49 & 17.42 & 11.49 & 37.25 & 136.26 \\
\hline 15. & 2009 & 5.61 & 5.08 & 14.18 & 8.73 & 45.24 & 79.42 \\
\hline 16. & 2010 & 7.12 & 6.74 & 17.97 & 11.97 & 62.34 & 147.62 \\
\hline 17. & 2011 & 6.62 & 6.17 & 16.71 & 10.88 & 42.67 & 122.3 \\
\hline 18. & 2012 & 5.25 & 4.71 & 13.28 & 7.98 & 30.36 & 66.65 \\
\hline 19. & 2013 & 5.30 & 4.76 & 13.40 & 8.08 & 36.58 & 68.35 \\
\hline 20. & 2014 & 7.76 & 7.47 & 19.58 & 13.38 & 46.56 & 187.75 \\
\hline
\end{tabular}

Table.2 Estimation of groundwater recharge by water table fluctuation method for the period of $1995-2014$

\begin{tabular}{|c|c|c|c|c|c|}
\hline \multirow[t]{2}{*}{ Sl. No. } & \multirow[t]{2}{*}{ Year } & \multirow[t]{2}{*}{$\begin{array}{l}\text { Annual rainfall } \\
\qquad(\mathbf{m m})\end{array}$} & \multicolumn{2}{|c|}{$\begin{array}{l}\text { Difference in groundwater table level } \\
\text { (m) }\end{array}$} & \multirow[t]{2}{*}{$\begin{array}{l}\text { Annual recharge } \\
(\mathrm{mm})\end{array}$} \\
\hline & & & South West & North East & \\
\hline 1. & 1995 & 508.35 & 2.16 & 2.83 & 167.5 \\
\hline 2. & 1996 & 758.45 & 2.72 & 3.46 & 185.0 \\
\hline 3. & 1997 & 1154.55 & 3.17 & 3.52 & 87.5 \\
\hline 4. & 1998 & 772.75 & 2.31 & 3.66 & 337.5 \\
\hline 5. & 1999 & 856.35 & 2.97 & 3.51 & 135.0 \\
\hline 6. & 2000 & 749.25 & 1.83 & 2.48 & 162.5 \\
\hline 7. & 2001 & 776.45 & 1.90 & 2.63 & 182.5 \\
\hline 8. & 2002 & 416.2 & 0.89 & 1.23 & 85.0 \\
\hline 9. & 2003 & 676.25 & 1.74 & 2.01 & 67.5 \\
\hline 10. & 2004 & 843.85 & 2.11 & 2.83 & 180.0 \\
\hline 11. & 2005 & 982.8 & 3.10 & 3.58 & 120.0 \\
\hline 12. & 2006 & 860.1 & 2.13 & 2.95 & 205.0 \\
\hline 13. & 2007 & 711.1 & 1.78 & 2.43 & 162.5 \\
\hline 14. & 2008 & 945.05 & 2.67 & 3.21 & 135.0 \\
\hline 15. & 2009 & 717.7 & 1.86 & 2.46 & 150.0 \\
\hline 16. & 2010 & 990.5 & 2.75 & 3.32 & 142.5 \\
\hline 17. & 2011 & 889.2 & 2.37 & 3.73 & 340.0 \\
\hline 18. & 2012 & 666.6 & 1.27 & 2.05 & 195.0 \\
\hline 19. & 2013 & 673.4 & 1.18 & 1.57 & 97.5 \\
\hline 20. & 2014 & 1136.455 & 3.18 & 3.83 & 162.5 \\
\hline
\end{tabular}


Fig.1 Location of observation wells in the study area

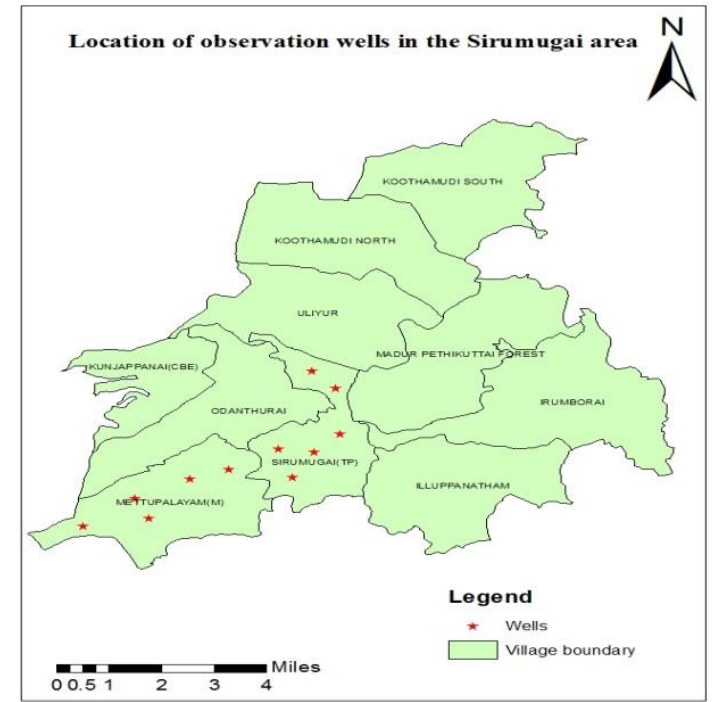

Fig.2 Long term distribution of mean monthly rainfall

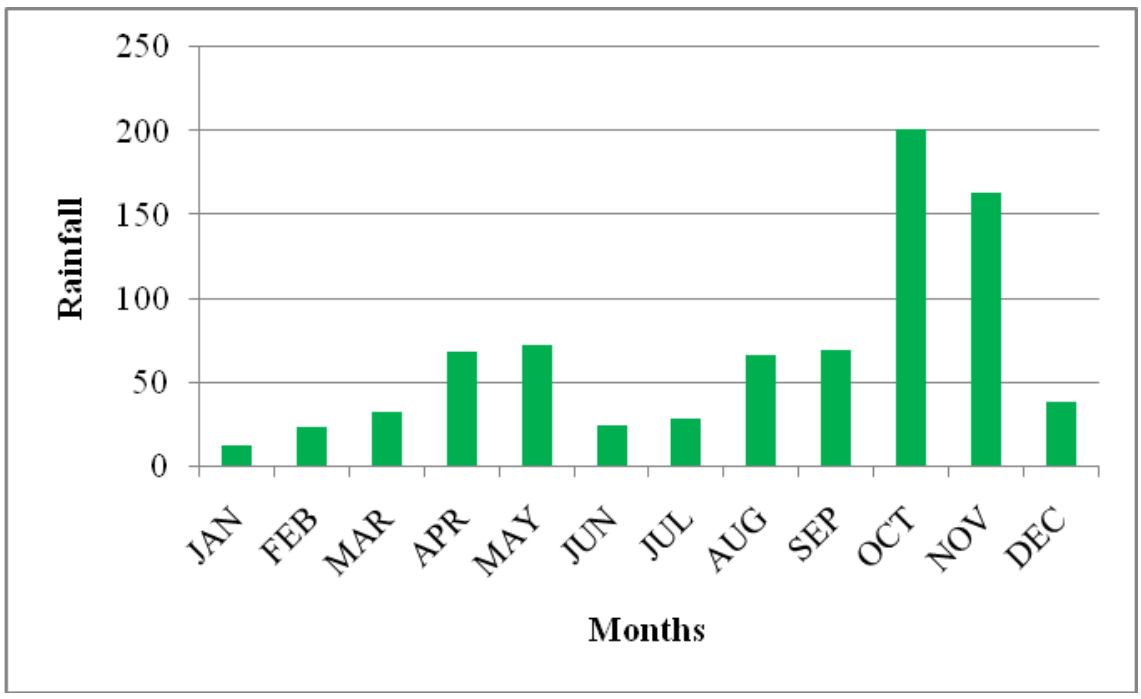

To estimate spatial variability in recharge by the WTF method, the average annual recharge for the period 1995 - 2014 was estimated for wells by using Equestion.8 from the estimates of mean annual $\ddot{\mathrm{A}} \mathrm{H}$ at each well and from estimates of Sy at each well. The results in Table 2 show that the recharge rates range from 67.5 to $340 \mathrm{~mm} / \mathrm{yr}$. Generally, recharge rates in the eastern part are higher than those in the west, as the topography is flat at these sites and the surface is covered by vegetation that makes a high percentage of the rainfall infiltrate into the aquifer.

\section{Comparison among methods}

The annual groundwater recharge calculated by using water level fluctuation method and 
empirical formulae were compared. The largest recharge estimates were usually determined by Krishna Rao formula and the smallest estimates were usually determined by U.P.I.R.I method. It was found that, during the period from 1995 to 2014, the annual groundwater recharge was on par with Water Level Fluctuation method and Krishna Rao formula. Among these methods, Water Level Fluctuation method and Krishna Rao formula shows reality in the Sirumugai study area. The results showed that average groundwater recharge of six empirical methods and water table fluctuation method were varies with 5.51 to $101.20 \mathrm{~mm}$ per year and 67.5 to 340 mm per year for the study area.

It is difficult to assess the accuracy of results from different methods as the true value of annual recharge is unknown. No single method can be termed the "best" at estimating recharge. Nevertheless, several conclusions can be arrived from this study about the advantages, disadvantages and limitations of the methods employed. Of the methods used in this study, the WTF method was the simplest and easiest to apply. Data requirements for the method are few and computations are less extensive. However, the method's success depends on reliable estimates of specific yield, a parameter that may be transient and spatially variable.

In this study, multiple methods for estimating groundwater recharge under different groundwater systems in the Sirumugai study area, Coimbatore, Tamil Nadu were used to identify the range of plausible recharge estimates, including the water-table fluctuation method and the empirical methods. With identified rain gauge stations on the inner area of Sirumugai, the total groundwater recharge for the entire study area was estimated by six empirical formulae and water table fluctuation method. The Krishna Rao formula slightly overestimated recharge due to the high average precipitation in the Sirumugai study area. The results showed that average groundwater recharge of six empirical methods and water table fluctuation method were varies with 5.51 to $101.20 \mathrm{~mm}$ per year and 67.5 to $340 \mathrm{~mm}$ per year respectively for the study area. Along with the previous studies, the results show that the annual groundwater recharge ranges from 16 to $32 \%$ of precipitation. None of the selected methods always produce the largest or smallest estimate of annual recharge for all groundwater systems. Comparison of multiple methods is found to be valuable for determining the range of plausible recharge rates and for highlighting the uncertainty of the estimates.

\section{References}

Bureau of Rural Science. (2007). Groundwater Recharge. Science for Decision Makers. Managing NonRenewable Groundwater Resources. BRS Publication.

Chaturvedi, R.S.1973. A Note on the Investigation of Ground Water Resources in Western Districts of Uttar Pradesh". Annual Report, U. P. Irrigation Research Institute, 1973, pp. 86-122

Clarke R (1991) Water: The International Crisis. Earthscan Publications Ltd., London, $193 \mathrm{pp}$

De Villiers M (2000) Water: the Fate of Our Most Precious Resource. Mariner Books, Houghton, Mifflin, Boston

Falkenmark M, Lundqvist J (1997) World Freshwater Problems - Call for a New Realism. UN/SEI, New York/Stockholm, $53 \mathrm{pp}$

Foster S (1998) Groundwater: assessing vulnerability and promoting protection of a threatened resource. Proceedings of the 8th Stockholm Water Symposium, 10-13 August, Sweden, pp. 79-90 
G.E.C. 2002. Draft report of the group for suggesting new and alternate methods of groundwater resources assessment. Central Groundwater Board, Ministry of Water Resources, Govt. of India.

Healy, R.W. and P.G., Cook. 2002. Using groundwater levels to estimate recharge. Journal Hydrogeology, 10: 91-109.

IWMI (2001) The Strategic Plan for IWMI 2000-2005. International Water Management Institute (IWMI), Colombo, Sri Lanka, $28 \mathrm{pp}$

Kumar, C.P. 1996. Assessment of Ground Water Potential. All India Seminar on small watershed development, organized by Indian Association of Hydrologists, West Bengal Center, 15 February, Calcutta.

Kumar, C.P. and P.V., Seethapathi. 2002. Assessment of natural ground water recharge in upper Ganga canal command area, Journal of Applied Hydrology, 15(4): pp. 13-20.

Risser, Dennis. W., Randall. W. Conger, James. E. Ulrich and Michael. P. Asmussen. (2005). Estimates of Ground Water Recharge Based on Stream Flow Hydrograph Method: Pennsylvania. http: //pubs.usgs.gov/of 2005/1333/.

Todd DK, Mays LW (2005) Groundwater hydrology. 3rd edition, John Wiley \& Sons, NJ, pp. 636

Tsakiris G (2004) Water resources management trends, prospects and limitations. Proceedings of the EWRA Symposium on Water Resources Management: Risks and Challenges for the 21st Century, 2-4 September 2004, Izmir, pp. 1-6

\section{How to cite this article:}

Natarajan P., S. V. Kottiswaran, A. Balasubramanian and Palanikumaran B. 2018. Groundwater Recharge Estimation Using Comparison of Methods in Sirumugai Area of Coimbatore, Tamil Nadu, India. Int.J.Curr.Microbiol.App.Sci. 7(06): 1433-1440. doi: https://doi.org/10.20546/ijcmas.2018.706.170 